Marquette University

e-Publications@Marquette

Economics Faculty Research and Publications

Economics, Department of

8-1-1987

\title{
On the Treatment of Income Tax Rates in Empirical Analysis of Tax Evasion
}

Steven E. Crane

Marquette University, steven.crane@marquette.edu

Farrokh Nourzad

Marquette University, farrokh.nourzad@marquette.edu

Accepted version. Kyklos, Vol. 40, No. 3 (August 1987):338-348. DOI. (C) 1987 Wiley. Used with permission. 


\title{
On the Treatment of Income Tax Rates in Empirical Analysis of Tax Evasion
}

\author{
Steven E. Crane \\ Department of Economics, Marquette University, \\ Milwaukee, WI \\ Farrokh Nourzad \\ Department of Economics, Marquette University, \\ Milwaukee, WI
}

\section{Introduction}

Income tax rates have long been recognized as a major determinant of income tax evasion. On a theoretical level, the consequences for evasion of changes in the tax rate have been analyzed under a variety of tax structures. The results have generally been indeterminate in that they depend on the shape of the tax function, the base of the penalty multiplier, the attitude towards risk, and whether or not true income and the detection probability are endogenous.

Most theoretical models explicitly account for only one tax rate: 'the' tax rate when a proportional system is assumed, and the marginal rate when a nonproportional tax structure is postulated. While the former treatment is appropriate given that under a 
proportional system there is but one tax rate, the latter may be overly simplistic. Under a nonproportional tax regime there is also an average tax rate which is typically different from the marginal rate. Traditional tax theory suggests that because these two rates tend to have differing effects, both should be accounted for when considering the overall effect of a tax rate change. Nevertheless, given that the results from theoretical evasion models using a single tax rate are already ambiguous, it is unlikely that adding this additional complication will lead to significant new insights.

In the empirical evasion literature, the general approach has been to follow the theoretical models and include only a single tax rate variable. With the exception of the game-simulation studies, these analyses have pertained to economies with progressive tax systems and therefore have included only a marginal tax rate variable, which has generally been found to have a significant positive impact on evasion. But there is a potential problem with this approach that has thus far gone unnoticed. To the extent that the average tax rate has an effect separate from that of the marginal tax rate, its exclusion from these models may lead to misleading results.

In this paper, we argue that the average tax rate does indeed have an effect on tax evasion which is separate from, and opposite to that of the marginal tax rate. Further, we contend that failure to explicitly account for this effect in an empirical evasion model will bias the parameter estimate of the marginal tax rate in a predictable manner. Finally, we provide some empirical evidence supporting these assertions.

\section{Theoretical Considerations}

The effect of tax rates on the income tax evasion decision of a risk averse individual was first analyzed by Allingham and Sandmo [1972], who considered a proportional tax regime where marginal and average tax rates are the same. They showed that, if detected evaders are subjected to fines which are imposed on evaded income, a change in the tax rate generates both an income and a substitution effect. In this case, if risk aversion is a decreasing function of income, the two effects oppose each other so that the total effect on reported income

Kyklos, Vol. 40, No. 3 (Fall 1987): pg. 338-348. DOI. This article is (C Wiley and permission has been granted for this version to appear in e-Publications@Marquette. Wiley does not grant permission for this article to be further copied/distributed or hosted elsewhere without the express permission from Wiley. 
is, a priori, ambiguous. In an important note on Allingham and Sandmo's article, Yitzhaki [1974] showed that, if taxes are proportional and fines are levied on evaded taxes rather than on evaded income, there is no substitution effect. As a result, if risk aversion is a decreasing function of income, the effect on reported income of a change in the tax rate is positive.

Subsequent theoretical studies [e.g. Pencavel, 1979 and Koskela, 1983] have extended the analysis to incorporate progressive tax systems, where marginal and average tax rates can be different ${ }^{1}$. For example, Pencavel has shown that Yitzhaki's finding applies to the marginal tax rate when the tax function is either linear- or nonlinearprogressive ${ }^{2}$. However, if true income is made endogenous through the introduction of a labor-leisure trade off, the effect on evasion of a change in the marginal tax rate is indeterminate when taxes are progressive in either sense. He has also pointed out that, regardless of the shape of the tax function, the properties of the risk aversion function, or whether or not true income is endogenous, the effect of a change in the marginal tax rate is indeterminate if the probability of detection is endogenous.

Under a progressive tax system, however, the individual's decision is affected not only by the marginal tax rate but also by other factors related to the underlying tax structure. One such factor is the average tax rate. If the average tax rate is altered through changes in the level of exemptions, the intra-marginal tax rates, or nontaxable governmental lump-sum transfers, etc., taxpayers are likely to respond by modifying their evasion behavior for any given marginal tax rate.

Traditional tax theory suggests that, unlike changes in the marginal tax rate, changes in the average tax rate generate only an income effect. This is because a change in the average tax rate only affects disposable income, whereas a change in the marginal tax rate affects not only disposable income but also relative prices. A similar result might be expected with respect to the evasion decision. If this is so, and if decreasing risk aversion is assumed, an increase in the average tax rate should have a negative influence on evasion, ceteris paribus. $^{3}$

Kyklos, Vol. 40, No. 3 (Fall 1987): pg. 338-348. DOI. This article is @ C Wiley and permission has been granted for this version to appear in e-Publications@Marquette. Wiley does not grant permission for this article to be further copied/distributed or hosted elsewhere without the express permission from Wiley. 
Although the effect of changes in the average tax rate under a progressive tax system has not been explicitly analyzed in the theoretical evasion literature, insight can be gained from the existing analyses of the effect of governmental transfers and exemptions. With the marginal tax rate and before-tax income constant, both of these have been found to be positively related to unreported income if risk aversion is a decreasing function of disposable income. This holds regardless of the specification of the penalty function [Pencavel, 1979 and Koskela, 1983).

These results are consistent with those expected from changes in the average tax rate and they hold because, like a change in the average tax rate, changes in these factors generate only an income effect. In fact, with marginal tax rates and before-tax income constant, an increase (decrease) in the level of exemptions or lump-sum transfers reduces (increases) the average tax rate. Thus, one might reasonably conclude that the theoretical evasion literature provides some support for expecting a negative relationship between the average tax rate and evasion. However, given Pencavel's [1979, pp. 123-124] characterization of these and other theoretical results as' ... rest(ing) on fragile premises ... ', and his call for' ... a healthy infusion of empirical work to confront these hypotheses with actual behavior and to resolve the ambiguities ... ' it seems best to approach this question from an empirical perspective.

\section{Empirical Analysis}

As mentioned above, previous empirical models of evasion have generally followed the theoretical studies and have thus included only a marginal tax rate variable. The results indicate that this variable has a significant positive effect on evasion [Clotfelter, 1983 and Crane and Nourzad, 1985,1986]. However, if the average tax rate exerts a separate influence on evasion, its omission from empirical models can result in biased and inconsistent parameter estimates.

Of the explanatory variables included in empirical models, the marginal tax rate is most likely to be plagued by these problems. Fortunately, it is possible to infer the direction of this bias from our earlier discussion of the expected effect of the average tax rate. If

Kyklos, Vol. 40, No. 3 (Fall 1987): pg. 338-348. DOI. This article is (C) Wiley and permission has been granted for this version to appear in e-Publications@Marquette. Wiley does not grant permission for this article to be further copied/distributed or hosted elsewhere without the express permission from Wiley. 
average and marginal tax rates do have opposing effects on evasion, and if they are positively correlated in sample data, the parameter estimate of the marginal tax rate will be biased downward when the average tax rate is excluded from the model.

In order to examine these issues we proceed as follows. First, we estimate an aggregate empirical model of evasion similar to one we have developed elsewhere for testing other hypotheses regarding tax evasion [Crane and Nourzad, 1985]. This model serves as a benchmark since, like most empirical models, it contains only the marginal tax rate as one of the explanatory variables. We should find that, as in previous studies, the marginal tax rate has a significant positive effect on evasion.

Second, we add an average tax rate variable to the benchmark model, and re-estimate the expanded model. We expect to find that the marginal tax rate remains positive and significant, but that the average tax rate has a significant negative effect. Finally, we compare the estimated coefficient of the marginal tax rate in this expanded model with that of the benchmark model. We should find the estimate from the expanded model to be larger, indicating the presence of the expected downward bias in the marginal tax rate coefficient of the single-tax-rate model.

Our benchmark model is given by:

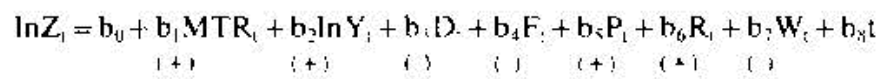

where $Z$ is unreported income, MTR is the marginal tax rate, $Y$ is true income, $D$ represents the probability of detection, $F$ is the fine or penalty rate to which evaders will be subjected if detected, $P$ is the inflation rate, $\mathrm{R}$ represents the real rate of interest, $\mathrm{W}$ is the wage and salary share of income, tis the time index, and the parentheses contain the expected sign for the corresponding coefficient. ${ }^{4}$

This benchmark model contains the four prime variables found in most theoretical and empirical models, MTR, Y, D, and F. It also includes two additional explanatory variables, $\mathrm{P}$, and $\mathrm{R}$, that elsewhere we have shown to influence tax evasion. ${ }^{5}$ Finally, the model includes an institutional variable, $W$, to control for the greater difficulty in underreporting income that is difficult to conceal. The expanded model

Kyklos, Vol. 40, No. 3 (Fall 1987): pg. 338-348. DOI. This article is (C Wiley and permission has been granted for this version to appear in e-Publications@Marquette. Wiley does not grant permission for this article to be further copied/distributed or hosted elsewhere without the express permission from Wiley. 
contains all of the above variables, along with an additional variable, the average tax rate, denoted ATR.

The measures used to quantify the variables in both models are briefly described in Appendix A. Here we limit our discussion to the tax rate measures which are the primary focus of this analysis. The marginal tax rate, MTR, in equation (I) is calculated using a procedure suggested by Wright [1969]. This involves summing the marginal rates in each year's tax schedule after weighting them by the fraction of total Adjusted Gross Income (AGI) in the corresponding tax bracket. The purpose of this variable is to capture the overall effect of changes in marginal tax rates embodied in the progressive income tax system of the US.

For the average tax rate variable, ATR, we use an aggregate measure suggested by Roth [1985). This is calculated by dividing total AGI by the number of returns filed, and expressing the base tax of the corresponding income bracket as a percent of the lower bound of that bracket. This approach to calculating the average tax rate was selected for the following reasons. First, ATR is an aggregate measure of the average tax rate, as is required for consistency with the rest of the model. Second. this measure can change without the marginal tax rate changing and vice versa, as is required by our analysis. Finally, given that income enters the model as a separate variable, this measure is less likely to introduce multicollinearity than other alternatives, such as an effective tax rate.

We estimated both the benchmark and the expanded model for the US over the years 1947-81 using an instrumental-variable approach". The results are shown in Table $I$. where equation $(A)$ is the benchmark, single-tax-rate model, and equation $(B)$ is the expanded model containing both tax rates.

Consider first equation (A). It is apparent that this model performs very well in that the $F$ and adjusted $\mathrm{R} 2$ statistics are quite high, the coefficients of all variables have the expected signs, and are generally significant. All three compliance-policy-related variables are negatively related to evasion. In contrast, the inflation, interest rate, income, and marginal tax rate variables are all positively related to

Kyklos, Vol. 40, No. 3 (Fall 1987): pg. 338-348. DOI. This article is (C) Wiley and permission has been granted for this version to appear in e-Publications@Marquette. Wiley does not grant permission for this article to be further copied/distributed or hosted elsewhere without the express permission from Wiley. 
aggregate evasion. These results are consistent with previous empirical findings [Clotfelter, 1983 and Crane and Nourzad, 1985).

Turning next to equation (B), we see that the coefficient of ATR is negative and significant at the usual levels, as expected, while that of MTR remains positive and significant. ${ }^{7}$ This provides clear support for our contention that both average and marginal tax rates matter. Further, the addition of ATR does not greatly affect the sign and significance of the other variables in the equation. However, the magnitudes of some of the parameter estimates are different from equation ( $A$ ). In particular, the MTR coefficient is now larger. This is consistent with our earlier argument that in the absence of ATR the coefficient of MTR can be expected to be biased downward. In fact, since ATR is statistically Steven E. Crane AND Farrokh Nourzad

Table I

Estimates of the logarithm of aggregate unreported income in the US, 1947-1981 (t-ratios in parentheses)

\begin{tabular}{|c|c|c|}
\hline Independent variables & $\begin{array}{l}\text { Equation }(A) \text { : } \\
\text { single-tax-rate } \\
\text { benchmark model }\end{array}$ & $\begin{array}{l}\text { Equation }(B) \text { : } \\
\text { double-tax-rate } \\
\text { expanded mode! }\end{array}$ \\
\hline $\mathrm{MTR}_{\mathrm{I}}$ & $\begin{array}{r}0.021 \\
(3.29)\end{array}$ & $\begin{array}{r}0.036 \\
(5.02)\end{array}$ \\
\hline ATR $_{1}$ & & $\begin{array}{c}-0.042 \\
(-3.20)\end{array}$ \\
\hline $\ln Y_{1}$ & $\begin{array}{r}0.065 \\
(3.19)\end{array}$ & $\begin{array}{r}0.077 \\
(4.35)\end{array}$ \\
\hline$D_{1}$ & $\begin{array}{r}-0.035 \\
(-2.05)\end{array}$ & $\begin{array}{r}-0.040 \\
(-2.73)\end{array}$ \\
\hline$F_{1}$ & $\begin{array}{r}-0.013 \\
(-2.86)\end{array}$ & $\begin{array}{r}-0.008 \\
(-2.06)\end{array}$ \\
\hline$P_{1}$ & $\begin{array}{r}0.112 \\
(4.33)\end{array}$ & $\begin{array}{r}0.130 \\
(5.74)\end{array}$ \\
\hline$R_{1}$ & $\begin{array}{r}0.108 \\
(375)\end{array}$ & $\begin{array}{r}0.128 \\
(5.09)\end{array}$ \\
\hline$w_{t}$ & $\begin{array}{r}-0.069 \\
(-3.50)\end{array}$ & $\begin{array}{r}-0.037 \\
(-1.89)\end{array}$ \\
\hline ' & $\begin{array}{r}0.013 \\
(1.87)\end{array}$ & $\begin{array}{c}0.002 \\
(0.32)\end{array}$ \\
\hline INTERCEPT & $\begin{array}{c}6.81 \\
(4.79)\end{array}$ & $\begin{array}{r}5.072 \\
(3.82)\end{array}$ \\
\hline$\overline{\mathbf{R}}^{2}$ & 0.98 & 0.99 \\
\hline $\mathbf{F}$ & 216.98 & 268.00 \\
\hline DW & 2.07 & 2.22 \\
\hline
\end{tabular}

different fom zero and is significantly positively correlated with MTR, the bias is statistically significant. ${ }^{8}$

Kyklos, Vol. 40, No. 3 (Fall 1987): pg. 338-348. DOI. This article is (C) Wiley and permission has been granted for this version to appear in e-Publications@Marquette. Wiley does not grant permission for this article to be further copied/distributed or hosted elsewhere without the express permission from Wiley. 
NOT THE PUBLISHED VERSION; this is the author's final, peer-reviewed manuscript. The published version may be accessed by following the link in the citation at the bottom of the page.

\section{Concluding Remarks}

Aside from the obvious implication for the specification of future empirical models of tax evasion, our findings have a bearing on a number of tax policy issues. For example, it has been argued that cutting marginal tax rates may be 'revenue neutral' partly because lower marginal rates will lead to greater reporting of income, and therefore, more tax revenue. The usual finding that the marginal tax. rate is positively related to income tax evasion lends some support to this argument. This claim is strengthened by the result reported in this paper that the effect on evasion of the marginal tax rate is larger when the average tax rate is taken into account.

Further, the result that the average tax rate is negatively related to evasion also has an implication for the tax reform issue. Financing 'revenue-neutral' cuts in marginal tax rates requires that revenues be raised from other sources, that the tax base be broadened, or that the intra-marginal tax rates by raised to offset the resulting revenue loss. The last approach would generally involve an increase in average tax rates. However, based on our findings, it appears that the increase necessary to achieve revenue neutrality need not be as great as might otherwise be expected because the increased average tax rate should bring about a further reduction in evasion.

Finally, given the opposing effects of marginal and average tax rates on evasion, a tax-cut package that reduces both rates should require significant 'supply-side' effects if revenue neutrality is to be achieved. In fact, in our sample the sum of the two tax rate coefficients is not significantly different from zero, suggesting that equal cuts in the two rates are 'evasion neutral' so that supply-side effects would have to carry the entire burden of the cuts.

\section{Appendix A: Variable Construction}

This appendix draws heavily on Appendix $A$ in Crane and Nourzad [1985], and briefly describes the measures used for the variables in equation (I) other than the two tax rates which are discussed in the text. For data sources see Appendix $B$ in the above

Kyklos, Vol. 40, No. 3 (Fall 1987): pg. 338-348. DOI. This article is (C) Wiley and permission has been granted for this version to appear in e-Publications@Marquette. Wiley does not grant permission for this article to be further copied/distributed or hosted elsewhere without the express permission from Wiley. 
NOT THE PUBLISHED VERSION; this is the author's final, peer-reviewed manuscript. The published version may be accessed by following the link in the citation at the bottom of the page.

reference.

Unreported income, $\mathrm{Z}$. This is a modified version of the Adjusted Gross Income (AGI) Gap computed by the Bureau of Economic Analysis (BEA) by comparing a measure of AGI derived from the data in the National Income Accounts (BEA AGI) with that reported by the Internal Revenue Service (IRS). The AGI Gap is a measure of the unreported income received in the official economy, and does not include 'underground' income flows. It has been modified to remove from it an imputed value of the AGI of those not required to file tax returns.

True income, Y. The measure used is deflated BEA AGI that has been modified to eliminate the income of those not required to file tax returns.

Probability of detection, D This variable is calculated as the moving average of the current, one-year, and two-year lagged values of the percentage of total tax returns audited each year by the IRS.

Penalty rate, $\mathrm{F}$. This rate is the ratio of the additional taxes, penalties, and interest assessed by the IRS during the year in question, to the amount of taxes evaded. The denominator of this ratio is the product of the AG I Gap defined above and MTR. This specification ism keeping with the US practice of imposing penalties on evaded taxes rather than evaded income.

Inflation rate, $\mathrm{P}$. This is calculated as the rate of change of the Consumer Price Index.

Interest rate, $\mathrm{R}$. This is an average of the savings and time deposit rates converted into real terms by removing from it the inflation rate as defined above.

Wage and salary share, $\mathrm{W}$ This is the share of wages and salaries in national income.

Kyklos, Vol. 40, No. 3 (Fall 1987): pg. 338-348. DOI. This article is @ C Wiley and permission has been granted for this version to appear in e-Publications@Marquette. Wiley does not grant permission for this article to be further copied/distributed or hosted elsewhere without the express permission from Wiley. 


\section{Summary}

In this paper, it is argued that average tax rates exert an influence on income tax evasion separate from, and opposite to that of marginal tax rates. Failure to account for this effect in empirical evasion models biases the parameter estimate of the marginal rate in a predictable manner. Evidence from an aggregate empirical model of evasion in the US indicates that the marginal tax rate is positively related to evasion, whereas the average tax rate is negatively related. Further, exclusion of the average rate from the model does in fact bias the parameter estimate of the marginal tax rate.

\section{References}

Allingham, M.G. and Sandmo, A.: 'Income Tax Evasion: A Theoretical Analysis', Journal of Public Economics, Vol. I (1972), pp. 323-338.

Clotfelter, CT.: 'Tax Evasion and Tax Rates: An Analysis of Individual Returns', Review of Economics and Statistics. Vol. 65 (1983), pp. 363373.

Crane, Steven E. and Nourzad, Farrokh 'Inflation and Tax Evasion. An Empirical Analysis', Rev1ew of Economic5 and Statistic5, Vol. 68 (1986), pp. 217-223.

Crane, Steven E. and Nourzad, Farrokh: 'Time Value of Money and Income Tax Evasion Under Risk-Averse Behavior: Theoretical Analysis and Empirical Evidence', Public Finance/Finances Publiques, Vol. 40 (1985), pp. 381-393.

Koskela, E.: 'A Note on Progression, Penalty Schemes and Tax Evasion', Journal of Public Economics. Vol. 22 (1983), pp. 127-133.

Pencavel, John H.: 'A Note on Income Tax Evasion, Labor Supply, and Nonlinear Tax Schedules', Journal of Public Economics. Vol. II (1979), pp. 115-124.

Pindyck, Robert S. and Rubinfeld, Daniel L.: Econometric Models and Economic Forecasts, 2nd ed., New York: McGraw-Hill, 1981.

Roth, Timothy P.; 'Tax Rates. Income Flows, and Money Demand', Quarterly Review of Economics and Business. Vol. 25 (1985), pp. 74-84.

Srinivasan, T. N.: 'Tax Evasion: A Model', Journal of Public Econom1cs, Vol. 2 (1973), pp. 339-346.

Wright, Colin: 'Saving and the Interest Rate', in: Harberger, A.C. and Bailey, M.J. (eds.: 1, The Taxation of Income From Capital. Washington, D. C. Brookings Institute 1969, pp. 275-300.

Kyklos, Vol. 40, No. 3 (Fall 1987): pg. 338-348. DOI. This article is (C) Wiley and permission has been granted for this version to appear in e-Publications@Marquette. Wiley does not grant permission for this article to be further copied/distributed or hosted elsewhere without the express permission from Wiley. 
NOT THE PUBLISHED VERSION; this is the author's final, peer-reviewed manuscript. The published version may be accessed by following the link in the citation at the bottom of the page.

Yitzhaki, Shlomo: 'A Note on Income Tax Evasion: A Theoretical Analysts', Journal of Public Economics, Vol. 3 (1974), pp. 201-202.

\section{Notes}

1 It should be pointed out that Srinivasan [1973] was the first to develop a model of evasion with progressive taxes. However, he assumed risk neutrality.

2 A linear progressive tax system is one where the average tax rate rises with income but the marginal rate is constant. A nonlinear progressive system is one where both tax rates rise with income.

3 Of course, this ignores the complications that might arise from the specification of the penalty function.

4 The expected signs are based on the theoretical literature or previous empirical findings. For a summary of the rationale for these expectations, see Crane and Nourzad [1985].

5 For a discussion of the justification for including inflation and Interest rates in an aggregate model of evasion, see Crane and Nourzad [1985, 1986].

6 This estimation approach was used in recognition of the possible simultaneity between the dependent variable and the income and penalty variables. For more on this see the discussion in Appendix $A$ of Crane and Nourzad [1985]

7 Although the absolute values of these parameter estimates appear to be different, they are not statistically significantly different from each other $\left(F_{125}=0.333\right)$.

8 Econometric theory indicates that the omitted-variable bias equals the product of two terms: I) the parameter estimate of the omitted variable (ATR) when it is included in the 'true' model, and 2) the estimated coefficient of the variable which is suspected to be biased (MTR) obtained from a regression of the omitted variable (ATR) on all of the explanatory variables of the 'true' model, including the suspect variable (MTR) [Pindyck and Rubinfeld, 1981, pp. 128-130].

Kyklos, Vol. 40, No. 3 (Fall 1987): pg. 338-348. DOI. This article is (C) Wiley and permission has been granted for this version to appear in e-Publications@Marquette. Wiley does not grant permission for this article to be further copied/distributed or hosted elsewhere without the express permission from Wiley. 